\title{
Governments and Farmers' Preference toward True Shallot Seed Institution Model in Indonesia
}

\author{
Asma Sembiring ${ }^{1,}$, Agus Muharam ${ }^{2}$, Rini Rosliani ${ }^{1}$, and Sulusi Prabawati ${ }^{3}$ \\ ${ }^{1}$ Indonesian Vegetables Research Institute, Lembang-Bandung, Indonesia \\ 2 Indonesian Center for Agricultural Technology Assessment and Development, Bogor, Indonesia \\ 3 Indonesian Center for Horticulture Research and Development, Bogor, Indonesia
}

\begin{abstract}
Management of True Seed of Shallot (TSS) production is an important part of supporting Indonesia shallot seed availability. It should involve various parties such as governments, privates, and shallot farmers to guarantee TSS quality and quantity of TSS. The study aims to identify governments' and farmers' preferences toward TSS institutional model in Indonesia. The study was undertaken in East Java from March to August 2016. Twenty-eight respondents from around East Java were purposively selected. Four options of the institution model of shallot seed were offered. The data was analyzed using the Analytical Hierarchy Process. The result showed that the preferred institution model for TSS by the respondents was the first option. In the model, Indonesian Vegetables Research Institute provided the high quality of shallot bulb seed and produced TSS for Breeder Seed. Meanwhile, other Indonesian government seed bodies/private generated bulb seed for Breeder Seed. Then, the University/Assessment Institute of Agricultural Technology/private produced TSS and bulb seed for Foundation Seed.Furthermore, selected shallot breeders produced TSS and bulb seed for Stock Seed and Extension Seed. The model could solve shallot seed quality and quantity problems' as it engaged the competent institutions. Therefore, the model could be recommended for TSS production nationally.
\end{abstract}

\section{Introduction}

Shallot (Allium ascalonicum L.) is considered one of the high economic vegetables and has a prospective Indonesian market. A primary challenge to increase the shallot production is no guarantee for a high-quality shallot seed, both in quantity and quality throughout the year $[1,2,3]$.

The problem happens because there are no shallot seed institutions patterns applied in Indonesia, especially in local areas. The existing pattern of shallot seed institution patterns are traditional, such as a seed is produced by farmers, and no certification regulations are enacted to the seed. The seed - in the form of bulb seed- is used by farmers themselves [4], or they sell the seed among them in local or outside of their areas. As a result, the availability of high-quality shallot seed is deficient [5] and influences shallot consumption production. It keeps remains low.

\footnotetext{
*Corresponding author: rangkayoamah@,gmail.com
} 
Other problems in Indonesia's shallot seed are no strict separation between private and government institution roles in seed distribution. Moreover, the function of shallot seed institution in production and distribution is still limited.

True Seed of Shallot (TSS) offers an alternative in shallot seed production instead of the conventional shallot bulb seed. TSS is a multiplication of shallot through seed. The technology production of TSS has been introduced by Indonesian Vegetables Research Institute (IVEGRI) since 1989 and was developed intensively for the last seven years.

By using the TSS, higher production, improvement of seed health performance, and efficiency could be obtained [6,7]. Furthermore, the technology enables the seed to be stored longer in a warehouse and easier in maintaining and transporting it to other areas as well as an alternative to providing the shallot seed availability throughout the year in Indonesia [8].

Seed institution is an essential component that should be established to incentivize highquality seed production, independent, modern, and competitive in the future [9]. It will also influence seed productivity [10] and the seed program's success, as shown in Nepal [11]. TSS seed availability and distribution guarantee in the future from a source to users is needed to establish the appropriate TSS institution.

East Java is the second-largest shallot seed central production in Indonesia after Central Java. Its total production reached 243,087 ton in 2013 (24\% from national production and about 293,179 ton in 2014 (23.9\% of national production) [12]. The area also has potential highlands for TSS development. Since 2016, The TSS program development has been conducted in East Java [13].

Since East Java, there is no existing TSS institution, hence the study aims to identify the true shallot seed production institutional model in East Java based on the governments' and farmers' preference.

\section{Research Methods}

The study was conducted from March to August 2016 in East Jawa. A survey of governments and farmers' preference toward the shallot seed institution model through TSS in East Java was done during July 2016. Data were collected through 20 government respondents from the agricultural province and district/municipal governments. They were from Batu (2 respondents), Nganjuk (2), East Java Province (7), Kediri (1), Malang (3), Sumenep (1), Probolinggo (1), Kediri (1), and Assessment Institute of Agricultural Technology (AIAT) East Java (2). Also to 8 farmers and shallot seed grower respondents who were from around East Java. The respondents were selected purposively. All of them were actors who engaged in shallot seed chains in East Java. Moreover, the respondents would be the stakeholders involved in shallot seed development through TSS in East Java in the future.

The Data were analysed by using Analytical Hierarchy Process (AHP) as the method can be utilized to choose one option among several available options [14]. The models offered to respondents were based on the previous study, as shown in Figures 1, 2, 3, and 4 [15]. 


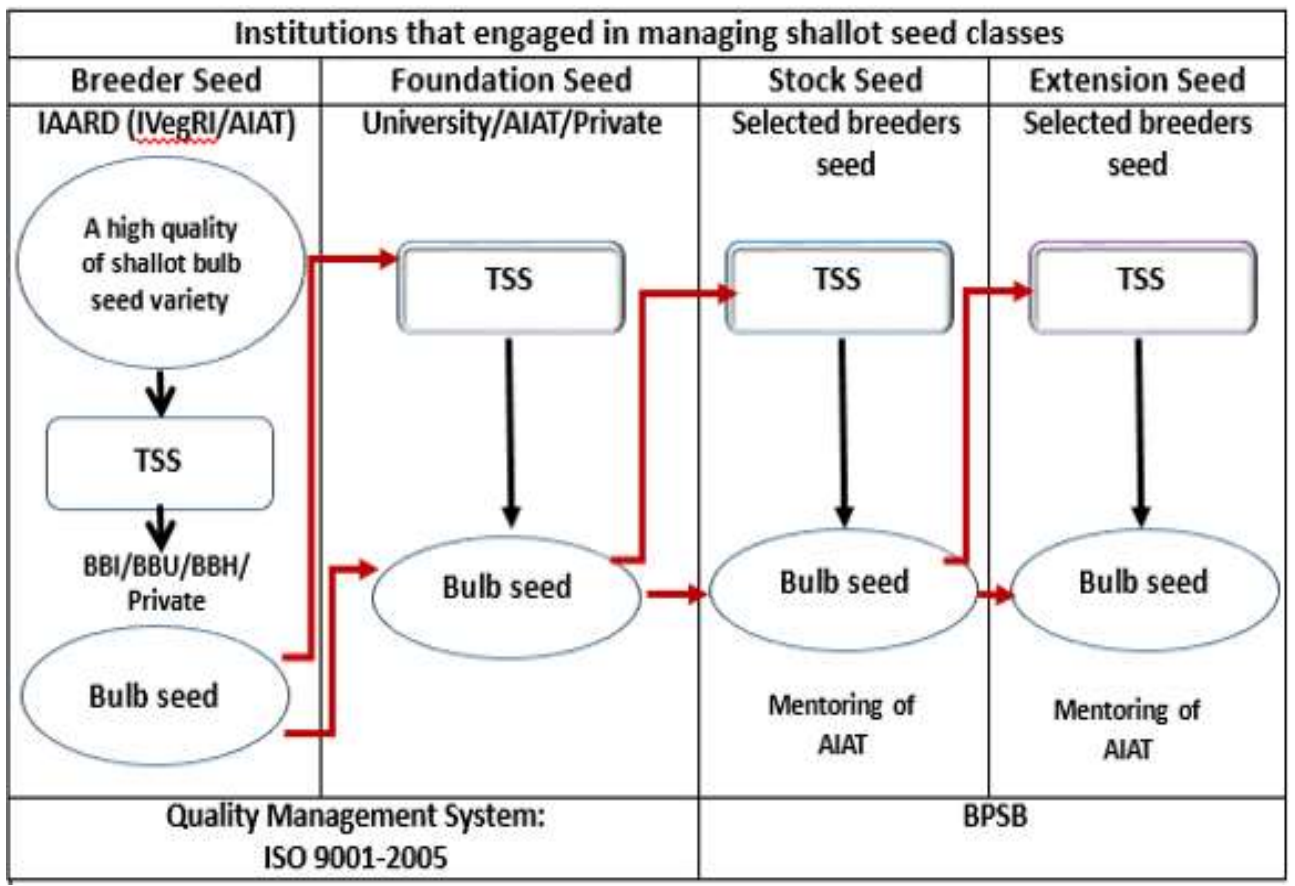

Fig.1. The first model development of TSS Shallot seed institutional in East Java

Note:

IAARD $=$ Indonesian Agricultural Agency Research and Development

BBI $=$ Parent Seed Institution

BBU = Main Seed Institution

$\mathrm{BBH}=$ Horticulture Seed Institution

BPSB $=$ Seed Certification and Inspection Office

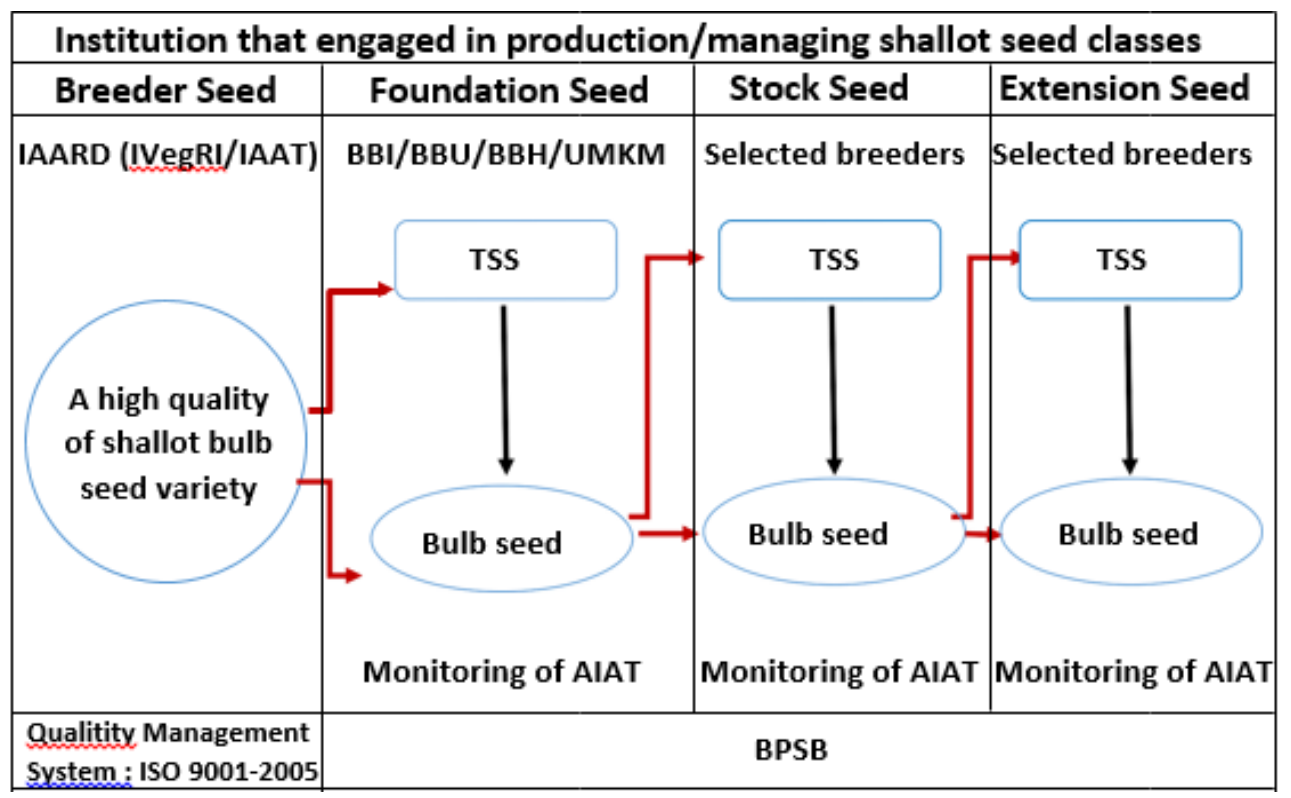

Fig.2. The second model development of TSS Shallot seed institutional in East Java 


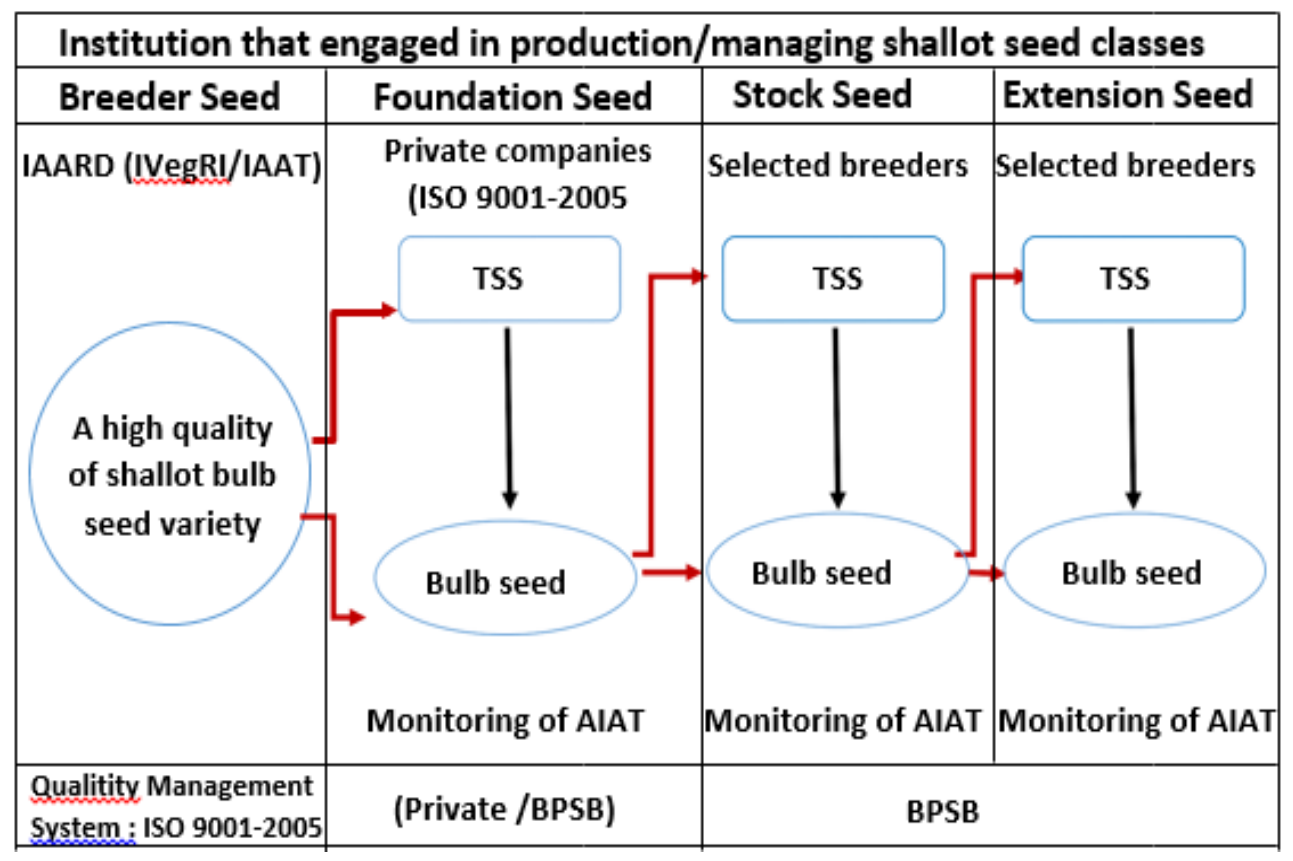

Fig.3. The third model development of TSS Shallot seed institutional in East Java

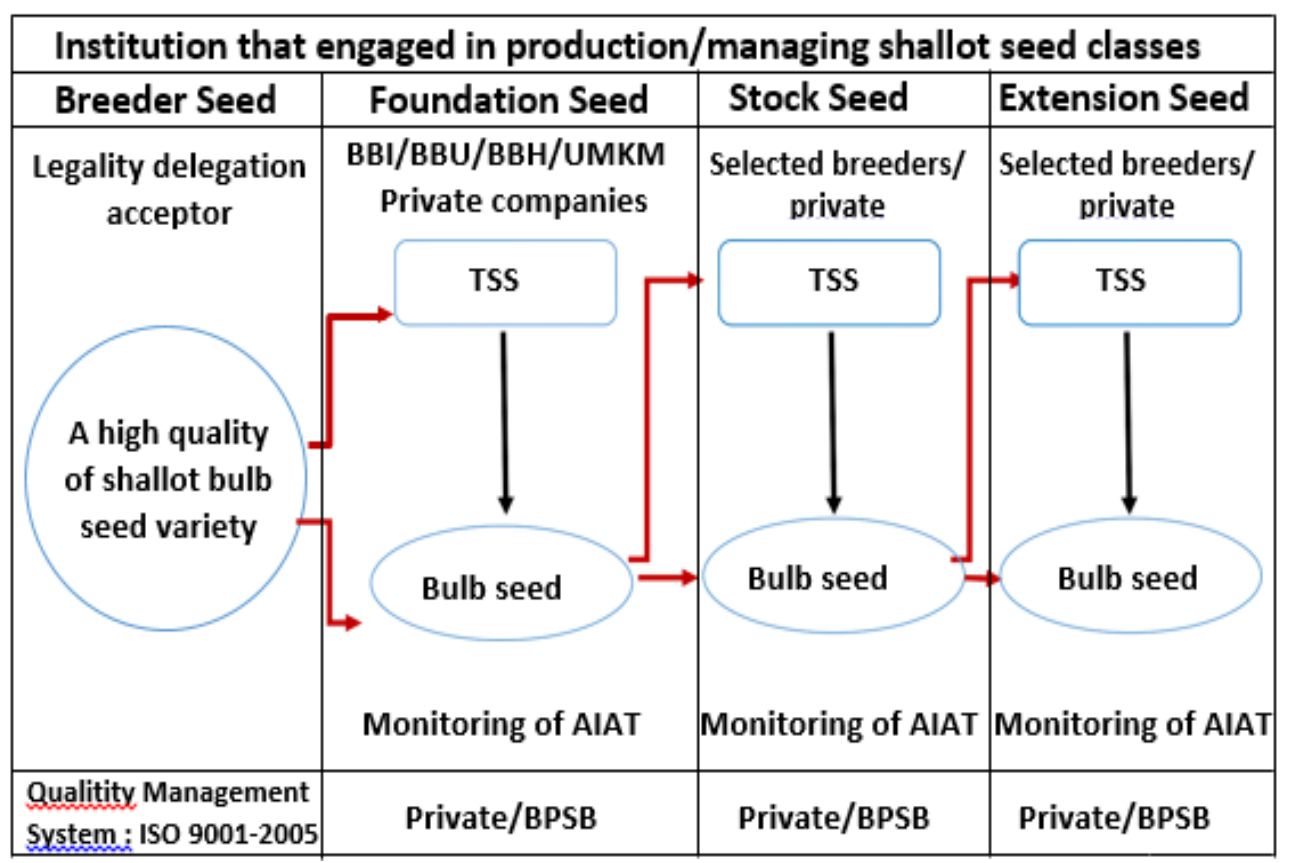

Fig.4. The fourth model development of TSS Shallot seed institutional in East Java

Note:

$\mathrm{UMKM}=$ Small and Medium enterprises

Meanwhile, the criteria were used to choose the institution model options covered 1) Quality 2) Acceleration 3) Profitable 4) Risk and 5) Continuity. Other factors which were necessary to be considered in choosing institution model options were roles of seed 
producers, which were included of 1) Producer of bulb and TSS for Foundation Seed (FS) class 2) Producer of bulb and TSS for Stock Seed (SS) class and 3) Producer of bulb and TSS for Extension Seed (ES) class. In addition to that, the scope covered 1) province and 2) District/municipal area development. The AHP of TSS institution model in East Java is described as shown in Figure 5 [15].

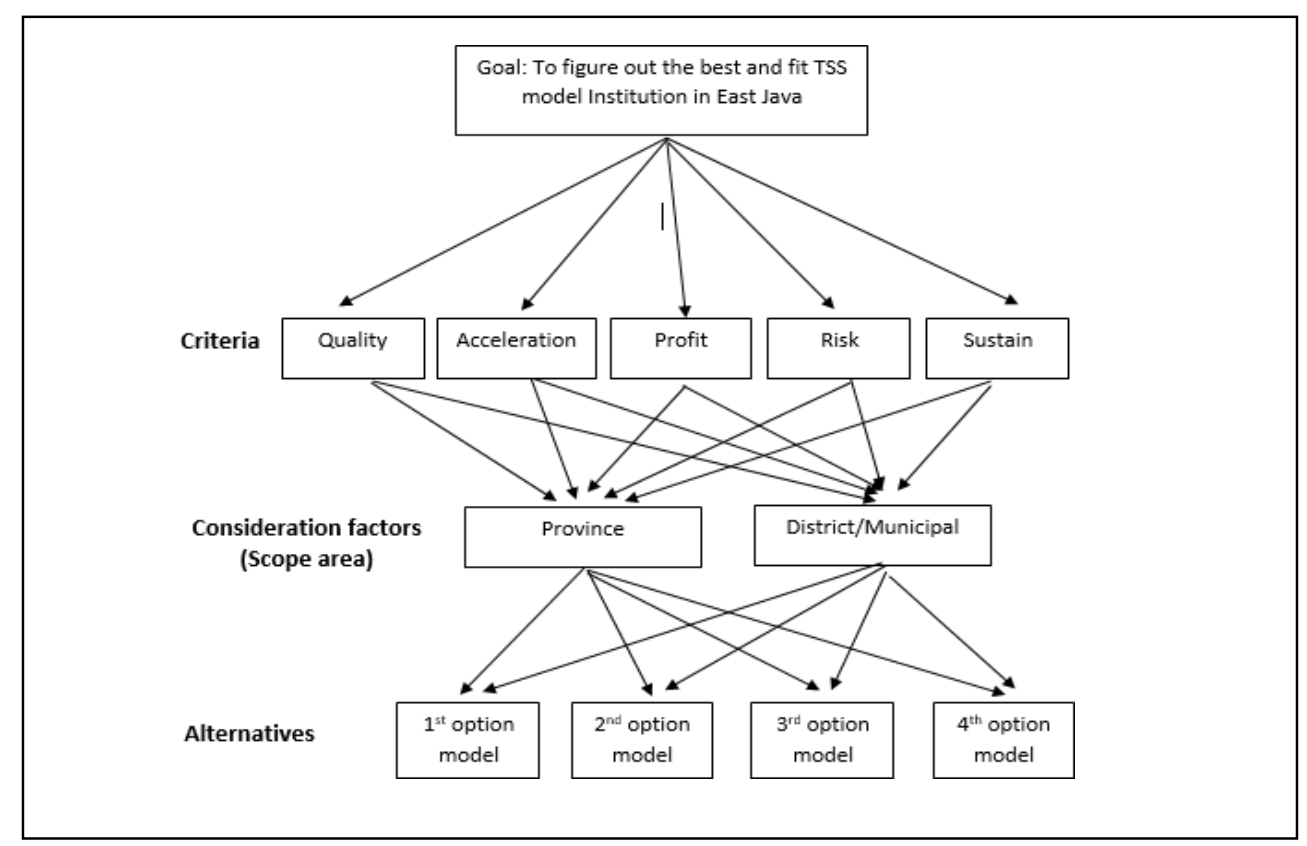

Fig. 5. The institution hierarchy model of TSS in East Java Province

\section{Results and Discussions}

\subsection{Government and farmer' preference toward TSS institution model option}

\subsubsection{Shallot institution model options based on criteria}

Based on the used criteria that produce a high-quality bulb seed, accelerating producing consumption bulb seed, creating optimal profit for shallot breeders, reducing farmer farming risk, and encouraging the shallot seed continuity. Therefore criteria generating a high-quality seed was the most crucial factor for the respondents compared to other criteria. It was shown by the score of $26.26 \%$ and $27.05 \%$, respectively. For the next important criteria, both respondents had different opinions. The governments indicated that accelerating generating consumption bulb seed and supporting the shallot seed continuity were the next important criteria with AHP score: $21.57 \%$ and $18.42 \%$. In the meantime, the farmers chose to reduce farmer farming risk and to encourage the shallot seed continuity as the following essential criteria with AHP score were $23.54 \%$ and $21.28 \%$, respectively, as shown in Table 1 .

Generating a high quality of shallot seed became a more important criterion for governments and farmers. Using the shallot seed's high quality would be better and induce a higher production [16]. Farmers' awareness to use high-quality shallot seed raise as their vegetable management system are more advanced [17].

Meanwhile, the governments' attention in providing a high quality of shallot seed could 
be seen from a government body's efforts such as IVEGRI to release the best vegetable seeds, issuing regulations to monitor vegetable seeds and seed distribution. Also, to establish vegetable seed agency certifications [13].

Table 1. Shallot institution model options based on criteria

\begin{tabular}{|l|c|c|}
\hline \multicolumn{1}{|c|}{ Criteria } & $\begin{array}{c}\text { Government } \\
\mathbf{n = 2 0}\end{array}$ & $\begin{array}{c}\text { Farmer } \\
\mathbf{n = 8}\end{array}$ \\
\hline & Inconsistency $: 0.03171$ & Inconsistency $: 0.08847$ \\
\hline 1. Quality & 0.26260 & 0.27052 \\
\hline 2. Acceleration & 0.21573 & 0.13248 \\
\hline 3. Profit & 0.15999 & 0.14886 \\
\hline 4. Risk & 0.17751 & 0.23538 \\
\hline 5. Continuity & 0.18416 & 0.21276 \\
\hline
\end{tabular}

\subsubsection{Role of seed producer institution to produce high-quality of TSS and shallot bulb seed.}

Regarding TSS producers, both of the respondents agreed that FS producer's role is the most important. FS producer's presence guaranteed continuity of the next seed class production and the quality and the truth of the variety. The AHP score for FS seed producers from governments and farmers as much as $56.12 \%$ and $53.01 \%$, respectively (Table 2).

Table 2. Seed producer institution role that needed to be prepared to generate a high quality of TSS and shallot bulb seed

\begin{tabular}{|l|c|c|}
\hline \multicolumn{1}{|c|}{ Institution } & $\begin{array}{c}\text { Government } \\
\mathbf{n = 2 0}\end{array}$ & $\begin{array}{c}\text { Farmer } \\
\mathbf{n = 8}\end{array}$ \\
\hline & Inconsistency $: 0.00000$ & Inconsistency $: 0.08847$ \\
\hline 1. FS producer & 0.56120 & 0.53009 \\
\hline 2. SS producer & 0.28206 & 0.30248 \\
\hline 3. ES producer & 0.15673 & 0.16743 \\
\hline
\end{tabular}

\subsubsection{Role of seed producer institution to accelerate shallot consumption production from TSS and the next seed classes.}

While for seed producer agency role that needed to be prepared to accelerate shallot consumption production for the next seed classes, both the respondents had a different opinion. According to the governments, the role of ES producers needed to be prepared. In the meantime, the farmers said that the role of FS required to be established. The AHP scores showed this were $46.01 \%$ and $71.88 \%$, respectively (Table 3 ).

The government institutions were very concerned about accelerating TSS technology innovation, particularly for a high-quality seed. Therefore the ES role should be prepared thoughtfully. The ES growers lived in shallot seed central production areas. Hence, the local governments were needed to coach the ES producers. On the contrary, farmers are more focused on using TSS's high quality from FS and SS. The farmers realized that if they use the seed carelessly, the shallot will be easy to attack by pests and diseases. Also, the plant will not grow in optimum condition. 
Table 3. Seed producer institution role that needed to be prepared to accelerate shallot consumption from TSS production and to the next seed classes

\begin{tabular}{|l|c|c|}
\hline \multicolumn{1}{|c|}{ Institution } & $\begin{array}{c}\text { Government } \\
\mathbf{n = 2 0}\end{array}$ & $\begin{array}{c}\text { Farmer } \\
\mathbf{n = 8}\end{array}$ \\
\hline & Inconsistency $: 0.00441$ & Inconsistency $: 0.00000$ \\
\hline 1. FS producer & 0.29278 & 0.71877 \\
\hline 2. SS producer & 0.24650 & 0.22189 \\
\hline 3. ES producer & 0.46072 & 0.05934 \\
\hline
\end{tabular}

\subsubsection{Role of seed producer institution to support the continuity of TSS.}

To support the continuity of TSS, both of the respondents had the same opinion. They said that it is needed to prepare FS producer role. The highest score of AHP indicated this was for FS producer role; they were $55.12 \%$ and $64.66 \%$, respectively, as shown in Table 4 .

Table 4. Seed producer institution role that needed to be prepared to encourage the continuity of shallot seed through TSS

\begin{tabular}{|l|c|c|}
\hline \multicolumn{1}{|c|}{ Institution } & $\begin{array}{c}\text { Government } \\
\mathbf{n = 2 0}\end{array}$ & $\begin{array}{c}\text { Farmer } \\
\mathbf{n = 8}\end{array}$ \\
\hline & Inconsistency $: 0.02823$ & Inconsistency $: 0.00000$ \\
\hline 1. FS producer & 0.55120 & 0.64662 \\
\hline 2. SS producer & 0.26806 & 0.27175 \\
\hline 3. ES producer & 0.18074 & 0.08163 \\
\hline
\end{tabular}

\subsubsection{Development area of shallot seed institution through TSS.}

In relation to the development area of shallot seed institutions through TSS, both respondents had similar views. The area should focus on the province rather than the district or municipal. It was shown by AHP score for the area was higher compared to district/municipal; they were $75.25 \%$ and $67.43 \%$, respectively (Table 5).

Table 5. Implementation scope for TSS development for FS producer institution

\begin{tabular}{|l|c|c|}
\hline \multirow{2}{*}{ Institution } & $\begin{array}{c}\text { Government } \\
\mathbf{n = 2 0}\end{array}$ & $\begin{array}{c}\text { Farmer } \\
\mathbf{n = 8}\end{array}$ \\
\cline { 2 - 3 } & Inconsistency $: 0.02823$ & Inconsistency $: 0.00000$ \\
\hline 1. Province & 0.75248 & 0.67427 \\
\hline 2. District and municipal & 0.24752 & 0.32573 \\
\hline
\end{tabular}

TSS can be produced only in particular areas such as $1000 \mathrm{~m}$ above the sea level $[18,19]$ and no mist in the area. In a province where a shallot central production area is located, not all districts have a suitable TSS production area. Therefore, it could be understood that government and farmer respondents preferred a province for TSS development for FS producer institution rather than in a district or a municipal.

\subsubsection{Scope implementation for TSS development for SS producer institution.}

In line with that, the respondents chose the province to fulfill SS for TSS. The SS for TSS could be produced in several districts/municipals and distributed to other districts in the same province. 
According to both of the respondents, the SS producer institution's TSS development was more important to be implemented in the province area. The AHP score from governments and farmers was $59.84 \%$ and $70.59 \%$, respectively, as shown in Table 6.

Table 6. Implementation scope for TSS development for SS producer institution

\begin{tabular}{|l|c|c|}
\hline \multicolumn{1}{|c|}{ Institution } & $\begin{array}{c}\text { Government } \\
\mathbf{n = 2 0}\end{array}$ & $\begin{array}{c}\text { Farmer } \\
\mathbf{n = 8}\end{array}$ \\
\cline { 2 - 3 } & Inconsistency $\mathbf{0 . 0 0 0 0 0}$ & Inconsistency $\mathbf{0 . 0 0 0 0 0}$ \\
\hline 1. Province & 0.59839 & 0.70588 \\
\hline 2. District and municipal & 0.40162 & 0.29412 \\
\hline
\end{tabular}

\subsubsection{Scope implementation for TSS development for SS producer institution.}

In related to the TSS development area for ES producer institution, there was different opinion between government and farmer respondents. The government considered that ES producer development implemented in the province was more important, with the AHP score was $50.98 \%$. On the other hand, the farmer chose ES producer development was more important to be applied in the district and municipal area. This shown by the AHP score was 84.04\% (Table 7). Developing ES producers in the district and municipal will ease farmers to access the shallot seed because farmers live closer to a district rather than to a province.

Table 7. Implementation scope for TSS development for ES producer institution

\begin{tabular}{|l|c|c|}
\hline \multicolumn{1}{|c|}{ Institution } & $\begin{array}{c}\text { Government } \\
\mathbf{n = 2 0}\end{array}$ & $\begin{array}{c}\text { Farmer } \\
\mathbf{n = 8}\end{array}$ \\
\cline { 2 - 3 } & Inconsistency $\mathbf{: 0 . 0 0 0 0 0}$ & Inconsistency $\mathbf{0} \mathbf{0 . 0 0 0 0 0}$ \\
\hline 1. Province & 0.50980 & 0.15966 \\
\hline 2. District and municipal & 0.49020 & 0.84043 \\
\hline
\end{tabular}

\subsubsection{The rank of TSS shallot seed institution option at province level.}

According to TSS shallot seed development in the province area, both government and farmer respondents had the same opinion. They chose the first institution option for the most suitable system model, with the AHP score were $49.15 \%$ and $38.58 \%$, respectively, as shown in Table 8. This may be because they have known how a research canter role in developing shallot seed through TSS and the capacities of other institutions who engaged in the model.

Table 8. TSS shallot seed institution option at province level

\begin{tabular}{|l|c|c|}
\hline \multicolumn{1}{|c|}{ Institution options } & $\begin{array}{c}\text { Government } \\
\mathbf{n = 2 0}\end{array}$ & $\begin{array}{c}\text { Farmer } \\
\mathbf{n = 8}\end{array}$ \\
\cline { 2 - 3 } & Inconsistency $\mathbf{: 0 . 0 0 0 0 0}$ & Inconsistency : 0.03493 \\
\hline $1^{\text {st }}$ institution option & 0.49153 & 0.38581 \\
\hline $2^{\text {nd }}$ institution option & 0.21361 & 0.30878 \\
\hline $3^{\text {rd }}$ institution option & 0.17020 & 0.18825 \\
\hline $4^{\text {th }}$ institution option & 0.12466 & 0.11716 \\
\hline
\end{tabular}




\subsubsection{The rank of TSS shallot seed institution option at district and municipal level.}

There was a different opinion between the respondents concerning TSS shallot seed institution option in the district and municipal areas. The government respondents tended to choose the $1^{\text {st }}$ institution option with AHP score of $48.12 \%$. In the meantime, farmers tend to the $2^{\text {nd }}$ institution option with AHP score of $29.91 \%$ (Table 9).

Table 9. TSS shallot seed institution option at district and municipal level

\begin{tabular}{|l|c|c|}
\hline \multirow{2}{*}{ Institution options } & $\begin{array}{c}\text { Government } \\
\mathbf{n = 2 0}\end{array}$ & $\begin{array}{c}\text { Farmer } \\
\mathbf{n = 8}\end{array}$ \\
\cline { 2 - 3 } & Inconsistency $\mathbf{~ 0 . 0 3 1 2 0}$ & Inconsistency : 0.03482 \\
\hline $1^{\text {st }}$ institution option & 0.48125 & 0.25375 \\
\hline $2^{\text {nd }}$ institution option & 0.21116 & 0.29911 \\
\hline $3^{\text {rd }}$ institution option & 0.17082 & 0.23291 \\
\hline $4^{\text {th }}$ institution option & 0.13677 & 0.22222 \\
\hline
\end{tabular}

In the context of the shallot production area, the farmers preferred a district/municipal as the scope area as they thought it would be easy for them to get the cheaper shallot seed and selling the shallot bulb consumption to the local markets.

\section{Conclusions and Implications}

Institutionalized shallot seed development through TSS is essential to guarantee the availability of the high quality and continuity nationally. Amongst the several institutional models assessed, the governments and farmers preferred that true shallot Breeder Seeds were produced by IVegRI and AIAT. Further, the seeds multiplied by regional government seed institutions, universities, private seed companies, and seed-producing farmers for the next seed classes. The Breeder Seed was under the supervision and licensed of IVEGRI. Meanwhile, the Seed Certification and Inspection Office inspected the Stock Seed and Extension Seed. The model is expected to solve shallot seed quality and quantity in East Java as it engaged the competent institutions, from government institutions to non-government institutions. All institutionalized participants should be committed by getting involved in every decision made. The model could be recommended TSS production nationally in Indonesia.

Acknowledgment. We thank the Indonesian Indonesian Agricultural Agency Research and Development for funding the research to Rima Setiani and AIAT East Java for their assistance to perform the study.

\section{References}

1. L.V. den Brink, R.S. Basuki, Acta Hortic. 958 (12), 115 (2012).

2. B. Sayaka, J. Hestina, Jurnal Forum Peneliti Agro Ekonomi. 29 (1), 27 (2011)

3. R.S. Basuki, J.Hort. 20 (2), 186 (2010).

4. SW. Manwan, Nurjanani, M.Thamrin, IOP Conf. Series: Earth and Environmental Science 484 (2020).

5. Saidah, A.R. Wahyuni, Muchtar, I.S. Padang, Sutardi, Asian Journal of Agriculture. 4 (1), 18 (2020). 
6. E.R. Palupi, M. Fatiani, M.R. Suhartanto, Journal of Tropical Crop Science. 4 (1). 26 (2017).

7. Shimeles, Journal of Agricultural Sciences. 59 (2), 129 (2014).

8. R. Rosliani, Y. Hilman, R. Sinaga, I.M. Hidayat, I. Sulastrini, J. Hort. 24 (4), 326 (2014)

9. ER. Palupi, R. Rosliani, Y. Hilman, J. Hort. 25 (1), 26 (2015)

10. J.Mariyono, A. Kuntaraningsih, T. Kompas, Management of Environmental Quality: An International Journal. 29 (2), 305 (2018).

11. K.D. Joshi, N.P. Khanal, D. Harris, N.N. Khanal, A. Sapkota, K. Khadka, R. Darai, R.K. Neupane, M. Joshi, J.R. Witcombe, Field Crops Research, 158, 15 (2014).

12. Badan Pusat Statistik (BPS), Jakarta, BPS, 214 (2015).

13. A.M Kiloes, Puspitasari, R. Rosliani Proceedings of International Syimposia on Horticulture (ISH); "Emerging Challenges and Opportunities in Horticulture Supporting Sustainable Development Goals", Kuta, Bali, Indonesia, 450-457 (2019).

14. Hefnawi, A.S. Mohammed, AS, International Journal of the Analytic Hierarchy Process, 6 (1), 92 (2014).

15. Sembiring, A. Muharam, R. Rosiliani, R. Setiani, Jurnal Hortikultura. 28 (2), 259 (2018).

16. Sembiring, IOP Conf. Series: Earth and Environmental Science 58 (2017).

17. E. Iriani, Jurnal Litbang Provinsi Jawa Tengah. 11(2), 231 (2013).

18. O.A. Khorasgani, M.Pessarakli, Journal Advances in Plants \& Agriculture Research. 9(2), 318 (2019).

19. H. Yusdar, R. Rosliani, E.R. Palupi, J. Hort. 24 (2), 154 (2014). 